\title{
Pareto analysis: diagnosing investments in managerial ego
}

\author{
C.G. Robinson
}

School of Business Leadership, University of South Africa, Pretoria

\begin{abstract}
Managers frequently state that $80 \%$ of profits or sales are derived from $20 \%$ of the product range. Though lip service is paid, the concept often is not applied as a tool for resource allocation and discrimination between a portfolio of products or business units. This article explains how managers can use the technique of Pareto analysis to identify different strategic categories as a guide to the allocation of resources and management attention.
\end{abstract}

S. Afr. J. Bus. Mgmt. 1983, 14: $109-112$

Bestuurders se dikwels dat $80 \%$ van winste of verkope van $20 \%$ van die produkreeks verdeel word. Hoewel dit dikwels gesê word, word hierdie konsep selde toegepas as 'n metode vir hulpbrontoewysing en onderskeiding tussen 'n portfolio van produkte of bedryfseenhede. Hierdie artikel verduidelik hoe bestuurders die tegniek van Pareto-analise kan gebruik om verskillende strategiekategorieë te identifiseer as ' $n$ gids vir die toewysing van hulpbronne en bestuursaandag.

S.Afr. J. BedryfsI. 1983, 14: $109-112$

\section{C.G. Robinson}

School of Business Leadership, University of South Africa,

P.O. Box 392, Pretoria 0001, Republic of South Africa.

\section{Introduction}

The economist Vilfredo Pareto proposed a law on distribution of income which is generally fairly accurate for above subsistence incomes. Pareto's law states that the number of individuals, $N$, from a given population of size, $a$, whose income exceeds $x$ is given by a power function of the form

$N=\frac{a}{x^{b}}$

where $b$ is a population parameter and differs from population to population, a value of approximately 1,5 being common. (Figure 1).

In management literature the law has been restated as the familiar eighty/twenty rule and provides a tool for diagnosing the corporate portfolio, whether at the product level or the strategic business level. In general corporate planners eschew mathematics and the broad concepts behind the eighty-twenty rule are usually applied in a non-mathematical form to segment products, or SBU's into strategic categories. The technique depends on stratifying the portfolio and in using the stratification analysis to pinpoint unprofitable members of the portfolio. Correctly applied the Pareto, or stratification, analysis can help diagnose investments in managerial ego that ought to be phased out of the portfolio.

The analysis can be carried out on a single variable such as profit or contribution margin but is best carried out in two dimensions using more than one indicator of business success. The potential use of the technique is best illustrated by considering one- and two-way stratification analyses.

\section{One-way Pareto analysis}

A set of sales values is given in Table 1. With a short product list as in Table 1 it is relatively easy to assess optically where the major sales emphasis happens to be. However with large product lists it is not so easy to see where the major sales emphasis happens to be. Management runs the risk of spending an inordinate amount of time on the less

Table 1 Raw sales data for one-way Pareto analysis

\begin{tabular}{cc} 
Product & Sales value $S$ \\
\hline 1 & 25000 \\
2 & 60000 \\
3 & 5000 \\
4 & 10000 \\
5 & 100000 \\
\hline
\end{tabular}


important products precisely because the relative importance of the products on the list have never been quantified.

One way of assessing the relative emphasis to be placed on products is by comparing the cumulative percentage of products with the cumulative percentage of sales.

Table 2 One-way Pareto analysis on sales data ${ }^{1}$

\begin{tabular}{ccrrrr}
\hline Product & $\begin{array}{c}\text { Product } \\
\text { list }\end{array}$ & $\begin{array}{c}\text { Sales } \\
\text { value S }\end{array}$ & $\begin{array}{c}\text { Cumulative } \\
\text { product } \\
\text { list } \%\end{array}$ & $\begin{array}{c}\text { Cumulative } \\
\text { sales }\end{array}$ & $\begin{array}{c}\text { Cumulative } \\
\text { sales } \%\end{array}$ \\
\hline 5 & $20 \%$ & 100000 & $20 \%$ & 100000 & $50 \%$ \\
2 & $20 \%$ & 60000 & $40 \%$ & 160000 & $80 \%$ \\
1 & $20 \%$ & 25000 & $60 \%$ & 185000 & $92,5 \%$ \\
4 & $20 \%$ & 10000 & $80 \%$ & 195000 & $97,5 \%$ \\
3 & $20 \%$ & 5000 & $100 \%$ & 200000 & $100 \%$ \\
\hline
\end{tabular}

Table 2 gives the one-way Pareto analysis. ${ }^{1}$ Firstly the products are ranked in order of sales. As there are five products, each product is one fifth of the product list or $20 \%$. The cumulative product sales are therefore $20 \%, 40 \%$ and so on. The sales are cumulated and a cumulative sales percentage is worked out. A Pareto curve is plotted relating cumulative sales to cumulative product list. The result is the familiar (eighty/twenty) curve given in Figure 1.

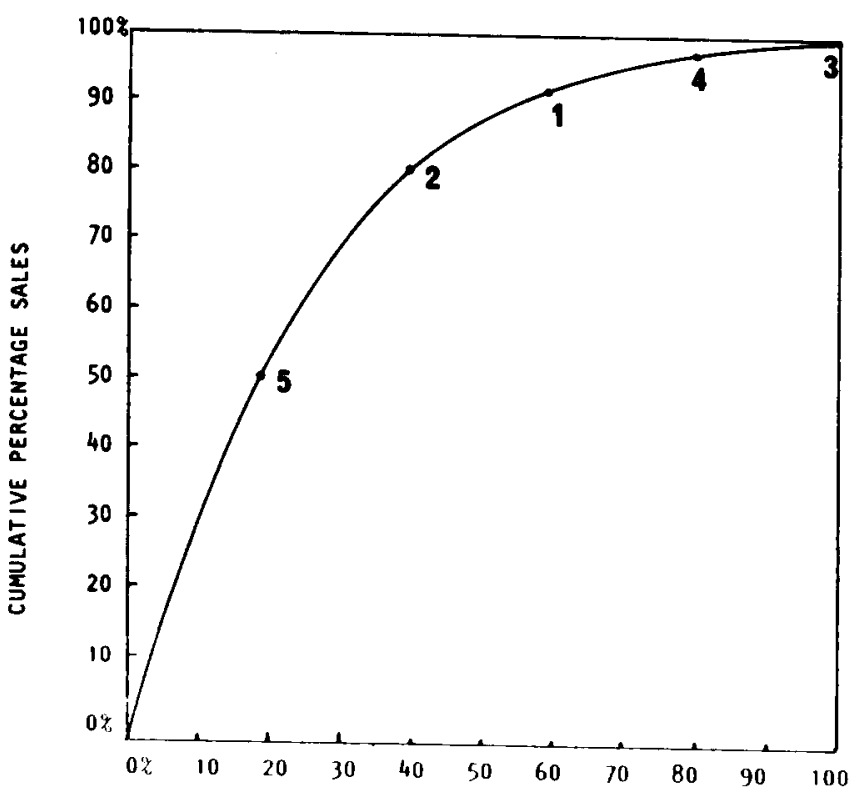

CUmulative percentage product LIST

Figure 1 Pareto curve for sales data

In general costs, expenses, sales by area, sales by customer and so on will result in a Pareto curve such as that given in Figure 1. Approximately $20 \%$ of the product list will generate $80 \%$ of the sales.

The objective of the exercise is to find out where management should be focussing its attention. For example it may be far more meaningful to press for a $10 \%$ increase in sales volume with a product that generates $50 \%$ of the sales than try for a $50 \%$ increase in sales with a product that generates only $3 \%$ of sales. In fact the low volume products should be carefully scrutinized with regard to their remaining in the portfolio at all, particularly if they consume large amounts of management time, finance or other resources.

When dealing with large numbers of products it helps to establish a classification system. It is typical to use a three way classification into $\mathrm{A}, \mathrm{B}$ and $\mathrm{C}$ products, or businesses. Somewhat arbitrarily, products can be defined:

- as A products if they help contribute toward the first $75 \%$ of sales,

- as B products if they help contribute to the next $15 \%$ of sales, falling between $75 \%$ and $90 \%$, and

- as $C$ products if they contribute to the last $10 \%$ of sales. This classification is purely arbitrary and a matter of judgement. Dependent on the planning circumstances it may be necessary to use a cut-off for A products at $70 \%, 80 \%$ or some other value, and a cut-off for B products at $80 \%$, $85 \%$ or some other value. This is illustrated by Figure 2 .



Figure 2 Product classification on the Pareto curve

On Figure 2 product 5 alone does not generate $75 \%$ of sales, only $50 \%$, which is considerably less than $75 \%$. By cutting at $80 \%$ products 5 and 2 are included as A category products. To get any $B$ category products it is necessary to cut at $92,5 \%$ which then includes product 1 as a B category product. Products 4 and 3 are $C$ category products. The categorization is then

$\begin{array}{cc}\text { Category } & \text { Products } \\ \text { A } & 5,2 \\ \text { B } & 1 \\ \text { C } & 4,3\end{array}$

The results of the one way Pareto analysis are already enough to begin to ask probing questions regarding the status of the $\mathrm{C}$ category products or businesses. Indeed the very rationale behind their existence should be under fire. 
The use of one-way Pareto analysis is of great use in answering questions on the level and type of inventory to be carried. When allied with concepts such as static marginal analysis, ${ }^{2}$ in which powerful profitability or service indices can be generated, Pareto analysis allows for policy statements on inventory holding levels at the functional area level and strategic statements at the corporate level. Inadequate attempts seem to have been made to use the technique on appropriate indices to help in strategic planning for service industries. Many potential applications must exist, in areas such as banking and insurance, if well designed ratios reflecting profitability, service level and so on can be calculated. Even more insight is made possible by using more than one index of merit: This leads naturally to the concept of twoway Pareto analysis.

\section{Two-way Pareto analysis}

It is possible to carry out Pareto analyses in more than one dimension. The stratification in two dimensions is used to critically examine a portfolio of products or businesses. A two-way Pareto analysis is simply composed of two one-way Pareto analyses and a matrix representation of the product categories.

Data on sales by product class and contribution to profits are given in Table 3. In Table 4 a one-way Pareto analysis by sales value is given and Table 5 gives a one-way Pareto analysis by profit contribution. Figures 3 and 4 graphically portray the results of the two analyses.

Table 3 Raw sales volume and profit contribution data for a two-way Pareto analysis

\begin{tabular}{ccc}
\hline Product class & $\begin{array}{c}\text { Sales } \\
\text { S's }\end{array}$ & $\begin{array}{c}\text { Contribution } \\
\text { to profits }\end{array}$ \\
\hline 1 & 6000 & 2900 \\
2 & 8000 & 3000 \\
3 & 2000 & 1000 \\
4 & 3000 & 1000 \\
5 & 11000 & 4000 \\
6 & 4000 & 2000 \\
7 & 1000 & 400 \\
8 & 5000 & 1500 \\
\hline
\end{tabular}

In Table 4 and Figure 3, the analysis by product class, cut-off values of $75 \%$ and $92,5 \%$ give the following categories:

- category A

- category B

products $5 ; 2 ; 1 ; 8$;

- category C products $3 ; 7$.

Using the same cut-off values of $75 \%$ and $92,5 \%$, for the analysis by contribution, the following categories emerge from Table 5 and Figure 3:

- category A

- category B

products $5 ; 2 ; 1 ; 6$;

- category C

products $8 ; 4$;

products $3 ; 7$.

The results of the two-way Pareto analysis are given in Figure 5. The position of each product is graphically por-
Table 4 One-way Pareto analysis by sales volume

\begin{tabular}{cccccc}
$\begin{array}{c}\text { Product } \\
\text { class }\end{array}$ & $\begin{array}{c}\text { Percentage } \\
\text { of } \\
\text { product } \\
\text { list }\end{array}$ & $\begin{array}{c}\text { Cumulative } \\
\text { tist } \\
\text { percentage }\end{array}$ & $\begin{array}{c}\text { Sales } \\
\text { value }\end{array}$ & $\begin{array}{c}\text { Cumulative } \\
\text { sales } \\
\text { value }\end{array}$ & $\begin{array}{c}\text { Percentage } \\
\text { of } \\
\text { cumulative } \\
\text { sales }\end{array}$ \\
\hline 5 & $12,5 \%$ & $12,5 \%$ & 11000 & 11000 & $27,5 \%$ \\
2 & $12,5 \%$ & $25,0 \%$ & 8000 & 19000 & $49,7 \%$ \\
1 & $12,5 \%$ & $37,5 \%$ & 6000 & 25000 & $62,5 \%$ \\
8 & $12,5 \%$ & $50,0 \%$ & 5000 & 30000 & $75,0 \%$ \\
6 & $12,5 \%$ & $62,5 \%$ & 4000 & 34000 & $85,0 \%$ \\
4 & $12,5 \%$ & $75,0 \%$ & 3000 & 37000 & $92,5 \%$ \\
3 & $12,5 \%$ & $87,5 \%$ & 2000 & 39000 & $97,5 \%$ \\
7 & $12,5 \%$ & $100,0 \%$ & 1000 & 40000 & $100,00 \%$ \\
\hline
\end{tabular}

Table 5 One-way Pareto analysis by profit contribution

\begin{tabular}{|c|c|c|c|c|c|}
\hline $\begin{array}{l}\text { Product } \\
\text { ctass }\end{array}$ & $\begin{array}{c}\text { Percentage } \\
\text { of } \\
\text { product } \\
\text { lis }\end{array}$ & $\begin{array}{c}\text { Cumulative } \\
\text { list } \\
\text { percentage }\end{array}$ & $\begin{array}{c}\text { Profit } \\
\text { contribution }\end{array}$ & $\begin{array}{l}\text { Cumulative } \\
\text { contribution }\end{array}$ & $\begin{array}{l}\text { Percentage } \\
\text { cumulative } \\
\text { contribution }\end{array}$ \\
\hline 5 & $12,5 \%$ & $12,5 \%$ & 4000 & 4000 & $25,0 \%$ \\
\hline 2 & $12,5 \%$ & $25,0 \%$ & 3000 & 7000 & $44,0 \%$ \\
\hline$t$ & $12,5 \%$ & $37,5 \%$ & 2900 & 9900 & $67,9 \%$ \\
\hline 6 & $12,5 \%$ & $s 0,0 \%$ & 2000 & 11900 & $74,4 \%$ \\
\hline 8 & $12,5 \%$ & $62,5 \%$ & 1500 & 13400 & $83,8 \%$ \\
\hline 4 & $12,5 \%$ & $75,0 \%$ & 1200 & 14600 & $91,3 \%$ \\
\hline 3 & $12,5 \%$ & $87,5 \%$ & 1000 & 15600 & $97,5 \%$ \\
\hline 7 & $12,5 \%$ & $100,0 \%$ & 400 & 16000 & $100,0 \%$ \\
\hline
\end{tabular}



Figure 3 One-way Pareto analysis by sales value

trayed on the grid. Insight into the positioning of each product can be obtained from the grid.

- Products 5, 2 and 1 are major sellers and contribute most to profits. They should be examined carefully as they may be vulnerable to competitive attack. Conversely, they may highlight major competitive strengths to be exploited further. 


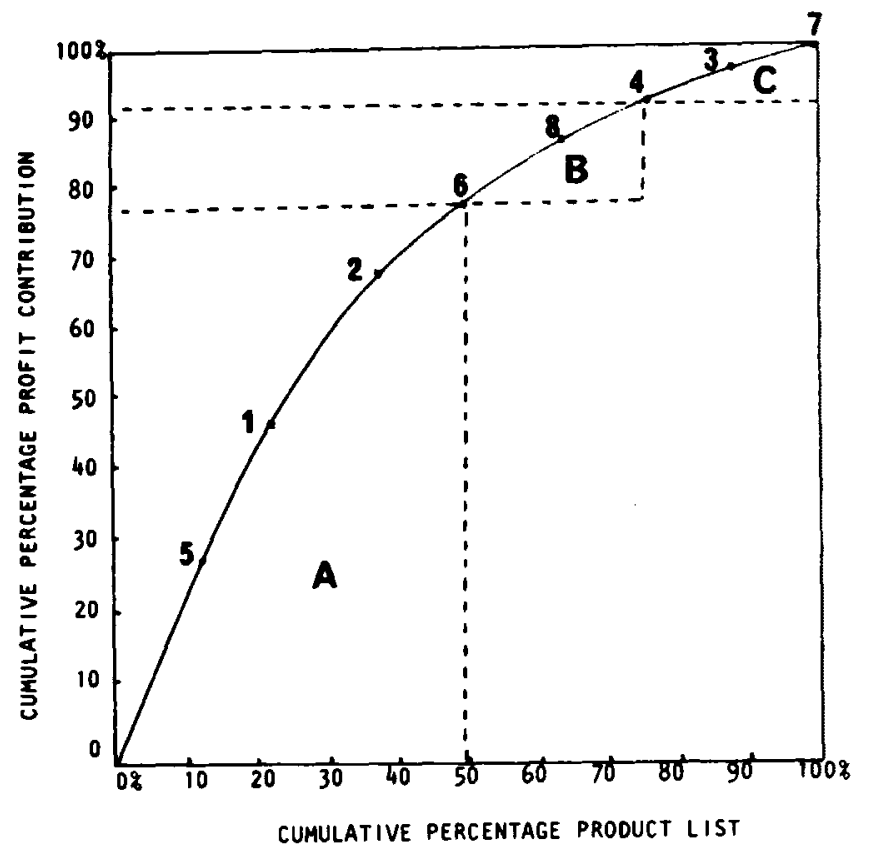

Figure 4 One-way Pareto analysis by profit contribution

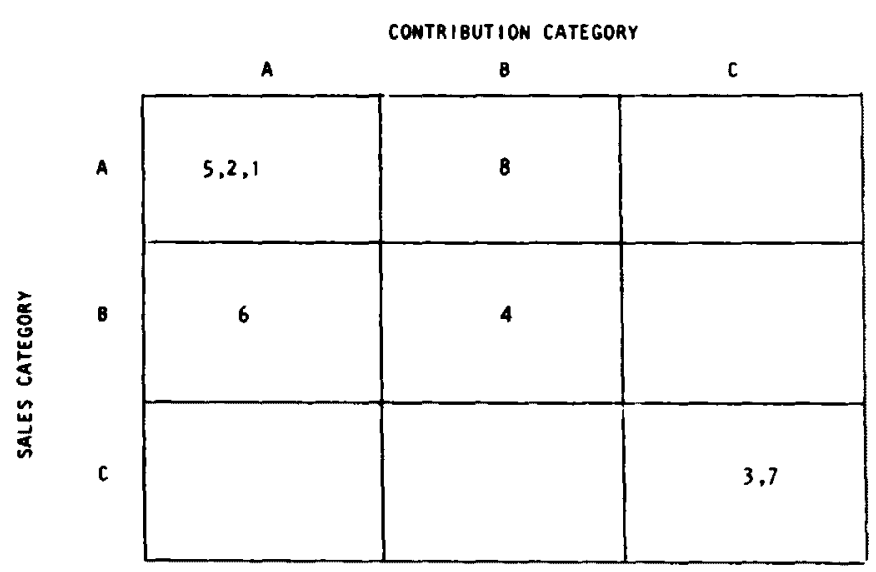

Fyure 5 Two-way Pareto analysis by sales and contribution

- Product 4 is an average seller and an average contributor. If it has been on the product list for some time it may merit a re-evaluation in terms of brand enhancement or some form of product repositioning. It may need phasing out and should be checked to see that it does not use too much of management's attention. If it is a new addition to the product line and a potential AA category product it should be managed and funded in the face of competitive action.
- Products 3 and 7 should be phased out or simply abandoned unless there is a good reason for keeping them. Exceptions may be the case of a newly launched product or a product essential to maintain the size of the product line. The product line should be ruthlessly pruned of losers which absorb management attention unnecessarily. All investments in managerial ego that have never, and will never, contribute should be winnowed from the product portfolio.

At the same time it is necessary to sound a word of caution. It is possible to be caught in the department store paradox, where after rigorous pruning of all non-effective departments the proprietor wakes up to the fact that he no longer has a department store. Pruning can be overdone.

- Product 6 is an average seller and an excellent profit contributor. It may be vulnerable to competitive attack particularly if it has created a price umbrella by generating very high margins. It is a key product for market development and consolidation if the market is growing. In a mature or declining market it indicates that a correct harvesting strategy is being carried out.

- Product 8 is an excellent seller but an average contributor to profits. The product may warrant a price increase, unless price discounting is consciously being carried out to improve market share. Methods of improving margins by quality control, repackaging or minor product enhancement may be called for.

\section{Conclusions}

One-way Pareto analysis provides a graphical method for quantifying the relative performance of a portfolio of products or businesses. Products, or businesses, are categorized dependent on how the product is positioned by comparing the sales, profit contribution or any other meaningful variables for the total range of products. Strategic categories of products are derived.

By using a two-dimensional grid each axis of which has been divided into strategic categories using a Pareto Analysis it is possible to gain deeper insights into the positioning of products. Pertinent questions can be generated and a balance found between management time and product performance. The strategic intent is to diagnose investments in managerial ego.

\section{References}

1. MacMillan, I.C. Pareto Analysis, Teaching Note No. 100/76, School of Business Leadership, University of South Africa, Pretoria, 1976. (Copyright UNISA)

2. Karr, H.W. and Geisler, M.A. A Fruitful Application of Static Marginal Analysis, Rand Corporation, Santa Monica, 1971. 